\title{
3D-STRUCTURES WITH INTEGRATION GEOLOGICAL AND GEOPHYSICAL DATA: IMPLICATION FOR RESEARCH WATER RESOURCES IN TUNISIA: CASE OF BOTH SE JEFFARA AND UTIQUE BASIN, TUNISIA
}

Sofien alyahyaoui $* 1,2$, Hedi Zouari ${ }^{1}$, Hakim Gabtni ${ }^{1}$, Chokri Jallouli ${ }^{2,3}$

${ }^{*}$ Georessources Laboratory, Water Researches and Technologies Centre, Borj Cedria Ecopark, BO 273, 8020, Soliman, TUNISIA

${ }^{2}$ Department of geology, Faculty of Sciences of Tunis, University Tunis El Manar, 2092 Manar II, TUNISIA

${ }^{3}$ Department of Geology and Geophysics, College of Sciences, King Saud University, P.O. Box. 2455, Riyadh 11451, SAUDI ARABIA

\section{Abstract:}

Tunisia is enriched by many natural resources (natural water and geothermal water) that are located along the South to the North. This paper aims mainly to evaluate the resources water potential. The available remote sensing images for two typical examples (SE Jeffara basin and Utique basin) are analyzed and many seismic profiles are interpreted to delineate the surface and subsurface structures.

The 3-D structures of Mio-Plio-Quaternary and Upper Cretaceous aquifers in South-East of Jeffara basin show an important reservoirs of water resources. The Upper Cretaceous aquifer "Complexe Terminal" is one of the most typical examples of exploitation features in hydrogeological research. It is formed by fractured limestones.

The 3D-structure of Utique basin shows an important variation of thickness of Mio-PlioQuaternary and Triassic series. The Mio-Plio-Quaternary series is formed by sand, clays and gypsum. The Triassic series is considered typical example for research the hydrogeological and hydrothermal water in Tunisia, especially in the North. In the subsurface, the triassic aquifer of Utique regions is formed by carbonates series. The hot spring in Utique basin is directly related to the Triassic dolostones which are extensively fractured [1].

A geophysical survey was undertaken for groundwater in Tunisia. The interpretation of seismic reflection sections and petroleum wells allowed to precise the geometry in subsurface structure.

Keywords:

3D-Structure, tectonic framework, water resources, SE Jeffara basin, Utique basin, Tunisia.

Cite This Article: Sofien alyahyaoui, Hedi Zouari, Hakim Gabtni, and Chokri Jallouli, "3DSTRUCTURES WITH INTEGRATION GEOLOGICAL AND GEOPHYSICAL DATA: IMPLICATION FOR RESEARCH WATER RESOURCES IN TUNISIA: CASE OF BOTH SE JEFFARA AND UTIQUE BASIN, TUNISIA" International Journal of Research - Granthaalayah, Vol. 3, No. 7(2015): 43-62. DOI: 10.29121/granthaalayah.v3.i7.2015.2985. 


\section{INTERNATIONAL JOURNAL OF RESEARCH -GRANTHAALAYAH

\section{INTRODUCTION}

Tunisia is situated in the north of Africa plate. The northern Africa is bounded by an Alpine-type orogen resulting from the subduction and closure of the Tethyan Ocean and from the interaction between the European and African plates [2] and [3]. In the north of Africa is situated the Maghrebian domain. The Digital Elevation Model view of the Maghrebian domain shows a generally decreasing elevation from north (chain Atlasic) to south (Saharan platform) (Fig. 1 a). Tunisia is considered to be one of the countries least well-endowed with water resources in the Mediterranean basin. It is characterized by a semi-arid climate with mild, dry summers, wet winters and warm. Pressure on fresh water demand is increasing as a result of demographic increase, agricultural water use and the development of the industry and tourism sectors. These conditions forced Tunisian authorities and policy makers to encourage for new research for potential resources water.

\section{GEOGRAPHICAL, GEOLOGICAL AND STRUCTURAL SETTING}

The Digital Elevation Model (DEM) of Tunisia, which shows a wide variation in the topography (Fig. 2). A maximum depth of $1600 \mathrm{~m}$ above sea level is the highly elevated mountainous in central Tunisia.

From the North to the South, the geological and structural context of Tunisia shows five domains:

1) The Tellian domain corresponds to "Alpine zone". This domain is characterized by the stacking of allochtonous units [4], [5], [6], [7], [8] and [9].

2) The Atlasic domain includes the Northern Atlas, the central Atlas and South Atlas.

3) The Northern Atlas is composed by imbricate thrust series [10] and [11 and salt outcrops zone is represented by NE-SW trending Triassic outcrops [12], [13], [14]. [11], [15], [16], [17]. [18], [19] and [20].

4) The Central Atlas is characterized by a NE-SW folds structures that are cut orthogonally by a graben system [21], [22], [23]. [24], [25] and [26].

5) The Southern Atlas is characterized by NW-SE and E-W to NE-SW folds [27], [28], [29]. [30], [31] [32], [28], [33], [34], [35], [36]. [37] and [38]. and bounded by the major faults Gafsa and Negrine-Touzeur.

6) The "North-South axis" is delimited the central Atlas zone and Eastern domain. It is composed by N-S trending faults [39], [40], [41]. [42], [43] and [44].

7) The Eastern domain is characterized by different blocks separated by N-S, E-S, NE-SW and NW-SE faults [45], [46], [47] and [48].

8) The Saharan domain is representing by folded Paleozoic rocks of African craton and Angular unconformity of Paleozoic series [49], [50], [51] and [52].

\section{METHODOLOGY}

This Research is based on the structural and strati graphical interpretation of surface data, 


\section{INTERNATIONAL JOURNAL OF RESEARCH -GRANTHAALAYAH \\ A knowledge Repository}

Science

seismic profiles and petroleum wells which lies in south-eastern and north eastern parts of Tunisia.

The utilized methods in this work are mainly applied to determine the following issues:

- The digital elevation model of SE Jeffara and Utique basins using remote sensing techniques;

- The surface and subsurface structure;

- 3-D structures of different basin;

- Subsidence structure;

- Deep fault system;

- The research water resources.

\subsection{TOPOGRAPHY}

The three-dimensional structures are displayed as their intersections with two-dimensional surfaces that may be defined analytically or with grid meshes in the case of irregular surfaces such as the digital terrain models.

The digital elevation model (DEM) of Tunisia shows a wide variation in the topography. The DEM of Tunisia is determined using remote sensing techniques. A maximum depth of 1600 meters is recorded at the highly elevated mountainous in central of Tunisia (Fig. 2)

The south-East Jeffara is situated in South-East of Tunisia. The digital elevation model of SE Jeffara basin is represented by different topographic relief of almost 0 meters to 650 meters (Fig. 3). The high topography relief is represented by mountains such as Jebel Tebaga and Dahar. The low topography relief is marked by lowland zones such as the Chotts and SE of Jeffara basin.

The DEM of north-eastern Tunisia (Fig. 4) is marked by different topographic relief of almost 0 meters to 600 meters. The high topography relief is represented by mountains such as Dj. el Messftine, Dj. Hakima and $\mathrm{Dj}$. Kechabta. The low topography relief is characterized by lowland zones such as the Utique plain.

\subsection{GEOPHYSICAL SURVEYS}

The resource mineral can be explored and used a variety of geophysical techniques and geological investigation as well as in the exploration of hydrocarbons and groundwater. In this study, geological and geophysical techniques (cross-section, wells petroleum and seismic 


\section{INTERNATIONAL JOURNAL OF RESEARCH -GRANTHAALAYAH \\ A knowledge Repository}

Science

profiles) used by to identify the major structures sub-basin aquifers and three dimension structures of study area.

\section{RESULTS AND DISCUSSION}

\subsection{CASE 1: SE JEFFARA BASIN}

In the SE Jeffara basin, two petroleum wells: W1 (Ben Guerdane-1), W2 (Bir Mastoura) and W3 (Utique-1) obtained from oils company (Mobile and SEREPT) and "Entreprise Tunisienne des Activités Pétrolières" (ETAP). The location of petroleum wells shows in figure 5. Eight seismic reflection profiles (L1 to L8) are analyzed (fig.5). The interpretation of these seismic profiles reveals to determine Mio-Plio-Quaternary and Upper Cretaceous aquifers.

The lithostratigraphical description from deep wells (W1 and W2) shows that fractured limestones and dolomitic of Upper Cretaceous to corresponding the lower part of "complexe Terminal". The Mio-Plio-Quaternary to corresponding the upper part of "Complexe Terminal" is formed by sand and silts.

The correlation of wells W1 and W2 [53], [54], [55] and [56].) Shows reduces series of Upper Cretaceous to corresponding to "Complexe Terminal".

The figure 5 shows the disappearance of the Upper Cretaceous unit and to reduce of the MioPlio-Quaternary series towards the southwest (W1 to W2).

The view 3D of geometry Mio-Plio-Quaternary and Upper Cretaceous aquifers of seismic profiles (figs. 5 and 6) The 3D view of combination seismic profiles (L1 to L8) shows the variations of the basin's geometry (Figs. 5 and 6). The variation of the thickness of the Upper Cretaceous is related by a horsts and grabens structure of the Upper Cretaceous and listric faults affected these series.

The 3-D blocks diagram representation of the top (Fig. 7) and the base (Fig. 8) of the Upper Cretaceous aquifer was determined using the seismic sections and borehole data (W1). Its shows that the basin increases in depth from the southwest toward the northeast and also the depth increases toward the southeast.

\subsection{CASE 2: UTIQUE BASIN}

In Utique basin, the petroleum well W3 is reached a total of 2500 meters. This well shows an important Triassic and Mio-Plio-Quaternary series. Four seismic profiles are analyzed.

In this study, analysis of the lithostratigraphic data was carried out using time-depth conversion wells data from W3. The processed seismic reflection profiles were obtained from "Entreprise Tunisienne des Activités Pétrolières" ETAP with the locations of profiles in Figure 9. 


\section{INTERNATIONAL JOURNAL OF RESEARCH -GRANTHAALAYAH \\ A knowledge Repository}

Science

The migrated seismic reflection profiles were analyzed to determine correlations between seismic reflection horizons and stratigraphic horizons determined from the boreholes W3.

All georeferenced subsurface and surface data are integrated, interrelated and analyzed using "midland valley" move 2014 software.

The Porto-Farina and Ariana region is characterized by Triassic to Quaternary series are derived from the geological mapping scale 1/ 50.000 [57], [58] and [59].

In subsurface, the well petroleum W3 shows that the Triassic series are formed by domination of fractured carbonates with an average porosity of $15 \%$ [60] and little gypsum.

Under the Miocene tortonian unconformity. Directly beneath the Miocene is a thin 11meter of late Cretaceous. The Mio-Plio-Quaternary is approximatly 1378 meter.

The Miocene and Pliocene are composed by sand, clay and little gypsum. The Quaternary substratum shows continental facies.

The different view 3D of interpretation in polygone of seismic profiles shows the geometry of repartition of Mio-Plio-Quaternary and Triassic series (figs. 10 and 11).

The figure 12 shows the top of the late Triassic aquifers is determined using the seismic sections and borehole data (W1). Its shows that the basin increases in depth from the southeast toward the northeastwest. The Triassic aquifer is formed by fractured dolostones and limestones. The Triassic aquifer is considerate a thermal aquifer [1] and it is favorable to the hydrogeological exploitation.

\section{CONCLUSIONS}

The integration of surface (geological mapping and outcrops) and subsurface studies (petroleum's well, seismic reflection profiles and gravity data) has given an idea of geometry in subsurface of aquifers for prospecting natural resources mineral. The Upper Cretaceous and MioPlio-Quaternary of "Complexe Terminal" aquifer in the Jeffara basin and the Triassic aquifer of Utique basin is considerate strategic a new aquifers exploration in the feature.

\section{ACKNOWLEDGEMENTS}

We express our appreciation to the SEREPT and ETAP for support and access to subsurface data (petroleum wells and seismic reflection lines). We wish to thank the society Midland Valley for access to use license academic move software 2014. 


\section{INTERNATIONAL JOURNAL OF RESEARCH -GRANTHAALAYAH

\section{REFERENCES}

[1] Andolssi, M., Alyahyaoui, S., Makni, J., Charef, A., Zouari, H., Tarki, M., Challouf, B., Integrated study of surface and subsurface data for prospecting hydrogeothermal basins of hot water spring Ain El Hammam: case of Utique region basin (Extreme North of Tunisia). Arab J Geosci. DOI 10.1007/s12517-014-1743-x. 2015.

[2] Auzende, J.M., Bonnin, J., Olivet, J.L., The origin of the western Mediterranean Basin, J. Geol. Soc. Lond. 129, 607-620, 1973.

[3] Domzig, A., Yelles, K., Le Roy, C., Déverchère, J., Bouillin, J.P., Bracène, R., Lépinay, B.M., Le Roy, P., Calais, E., Kherroubi, A., Gaullier, V., Savoye, B., Pauc, H., Searching for the Africa-Eurasia Miocene boundary offshore western Algeria. C. R. Géo. 338, 80-91, 2006.

[4] Jauzein, A., Rouvier, H., Sur les formations allochtones de Kroumirie (Tunisie septentrionale). C. R. Somm. Soc. Géol. 2, 36-38, 1965.

[5] Biely, A., Burollet, P.F., Lajmi, T., Etude géodynamique de la Tunisie et des secteurs voisins de la méditerranée. Notes Serv. Géol. Tunisie 41, 23-38, 1974.

[6] Ben Ferjani, A., Burollet, P.F., Mejri, F., Petroleum Geology of Tunisia: A Renwed Synthesis. Enterprise Tunisienne d'Activités Pétrolières, Mém. No.22, 2006.

[7] Ould Bagga, M.A., Saadi, A., Mercier, E., La "Zone des Nappes" de Tunisie: une marge méso-cénozoïque en blocs basculés modérément inversé (région de Tabarka/Jendouba; Tunisie nord-occidentale). Bull. Soc. Géol. France 177(3), 145-154, 2006.

[8] Boukhalfa, K., Ben Ismail-Lattrache, K., Riahi, S., Soussi, M., Khomsi, S., Analyse biostratigraphique et sédimentologiquen des séries éo-oligocènes et miocènes de la Tunisie septentrionale: implications stratigraphiques et géodynamiques. C. R. Geoscience 341, 49-62, 2009.

[9] Riahi, S., Soussi, M., Boukhalfa, K., Ben Ismail-Lattrache, K_., Dorrik, S., Khomsi, S., Bedir, M., Stratigraphy, sedimentology and structure of the Numidian Flysch thrust belt in Northern Tunisian. Journal of African Earth Sciences 57, 109-126, 2010.

[10] Zargouni, F., Etude géologique de la chaîne de Lansarine (région de Tebourba, Atlas tunisien). Thèse 3éme cycle, Univ. Pièrre et Marie Curie, Paris, 86 p, 1975.

[11] Perthuisot, V., Dynamique et pétrogenèse des extrusions triasiques en Tunisie septentrionale, Thè se d'Etat, Ecole Normale Supérieure, ERA 604-CNRS, 321 p, 1978.

[12] Burollet, P.F., Importances des facteurs salifères dans la tectonique tunisienne. Annales des Mines et de la Géologie de Tunisie 26, 11-120, 1973.

[13] Rouvier, H., Géologie de l'Extrême Nord-Tunisien : Tectoniques et paléogéographies superposées à l'extrimité orientale de la chaîne nord maghrébine. Thèse Doctorat es Sciences Univ. Pierre et Marie Curie, Paris VI, 1000 p. 1977. 


\section{INTERNATIONAL JOURNAL OF RESEARCH -GRANTHAALAYAH

[14] Zargouni, F., Etude structurale de la bande triasique de Baouala- Aroussia-El Mecherket (Zone de diapirs, Atlas tunisien). Bull. Soc. Sc. Nat. Tunis. t. 12, 79-82. 1977.

[15] Vila, J.M., Ben Youssef, M., Charrière, A., Chikhaoui, M., Ghanmi, M., Kammoun, F., Découverte en Tunisie au $S W d u$ Kef de matériel triasique interstratifié dans l'Albien : extension du domaine à " glacier de sel » sous-marin des confins algéro-tunisiens, C. R. Acad. Sci. Paris, Ser. II. 318, 109-116. 1994.

[16] Ghanmi, M., Ben Youssef, M., Jouirou, M., Zargouni, F., Vila, J.M., Halocinèse crétacée au Jebel Kebbouch (nord-ouest tunisien) : mise en place à fleur d'eau et évolution d'un " glacier de sel » albien, comparaisons. Eclogae Geologicae Helvetiae 94,153-160. 2001.

[17] Chikaoui, M., Jallouli, C., Turki, M.M., Soussi, M., Braham, A., Zaghbib-Turki, D., The Triassic rocks of the Debadib-Ben Gasseur area (northwestern Tunisia): diapirwith overhangs spreading downslope in the Albian Sea and deformed during the Tertiary compressional deformations. Comptes Rendus Geosciences 334, 1129-1133, 2002.

[18] Ben Chelbi, M., Melki, F., Zargouni, F., Mode de mise en place des corps salifères dans l'Atlas septentrionale de Tunis. Exemple de l'appareil de Bir Afou. C. R. Géoscience, 338, pp349-358, 2006.

[19] Masrouhi, A., Ghanmi, M., Ben Youssef, M., Vila, J.M., and Zargouni, F., Mise en évidence d'une nappe de charriage à deux unités paléogènes au plateau de Lansarine (Tunisie du Nord): Définition d'un nouvel élément structural de l'Atlas Tunisien et réévaluation du calendrier des serrages tertiaires: Comptes Rendus Géoscience, v. 339, p. 441-448, 2007.

[20] Masrouhi, A., Bellier, O., Koyi, H., Vila, J.M., Ghanmi, M., The evolution of the Lansarine-Baouala salt canopy in the North African Cretaceous passive margin in Tunisia. Geol. Mag. 150 (5 ), pp. 835-861, 2013.

[21] Jauzein, A., Contribution a' l'étude géologique des confins de la dorsale tunisienne (Tunisie Septentrionale), Thèse de Doctorat Ann. Mines Geol., no 22, Tunis, 475 p.

[22] Richert J.P., 1971. Mise en évidence de quatre phases tectoniques successives en Tunisie. Notes du Service Géologique de Tunisie 34, 115-125, 1967.

[23] Chihi, L., Dlala, M., Ben Ayed, N., Manifestations tectoniques synsédimentaires et polyphasées d'âge Crétacé moyen dans l'Atlas tunisien central (région de Kasserine). Comptes Rendus de l'Académie des Sciences de Paris 298 (II), 141-146. 1984.

[24] Frizon de Lamotte, D., Leturmy, P., Missenard, Y., Khomsi, S., Ruiz, G., Saddiqi, O., Guillocheau, F., Michard, A., Mesozoic and Cenozoic vertical movements in the Atlas system (Algeria, Morocco, Tunisia): An overview. Tectonophysics 475, 9-28, 2009.

[25] Zouaghi, T., Bédir, M., Abdallah, H., Inoubli, M.H., Seismic sequence stratigraphy, basin structuring, and hydrocarbon implications of Cretaceous deposits (Albian-Maastrichtian) in central Tunisia. Cretaceous Research 30, 1-21, 2009.

[26] Zouaghi, T., Ferhi, I., Bédir, M., Ben Youssef, M., Gasmi, M., Inoubli, M.H., Analysis of 


\section{INTERNATIONAL JOURNAL OF RESEARCH -GRANTHAALAYAH \\ A knowledge Repository}

Science

Cretaceous (Aptian) strata in central Tunisia, using 2D seismic data and well logs. Journal of African Earth Sciences 61, 38-61, 2011.

[27] Burollet, P.F., Contribution à l'étude stratigraphique de la Tunisie centrale. Ann. Mines.Géol., Tunis, $n^{\circ} 18,350$ p., 1956.

[28] Zargouni, F., Tectonique de l'Atlas méridional de Tunisie, évolution géométrique et cinématique des structures en zone de cisaillement. Thèse Doct. es-Sciences, Univ. Louis Pasteur Strasbourg, 292 p.1985.

[29] Ben Ayed, N., Évolution tectonique de l'avant-pays de la chaîne alpine de Tunisie du début du Mésozoïque à l'Actuel. Ann. Mines Geol., Editions du Service géologique de Tunisie, $n^{\circ} 32$, 286 p., 1993.

[30] Boukadi, N., Structuration de l'Atlas de Tunisie: signification géométrique et cinématique des noeuds et des zones d'interférences structurales au contact de grands couloirs tectoniques. Thése Doct.Univ. Tunis II, Fac. Des Sci. De Tunis, 248 p., 1994.

[31] Bouaziz, S., Barrier, E., Turki, M.M., Tricart, P., La tectonique permo-mésozoïque (antéVraconien) dans la marge sud téthysienne en Tunisie méridionale. Bulletin de la Société Géologique de France 170 (1), 45-56, 1999.

[32] Bouaziz, S., Barrier, E., Soussi, M., Turki, M.M., Zouari, H., Tectonic evolution of the northern African margin in Tunisia from paleostress data and sedimentary record. Tectonophysics 357, 227-253. 2002.

[33] Zouari, H., Evolution Géodynamique de l'Atlas Centro-Méridional de la Tunisie: Stratigraphie, Analyse Géométrique, Cinématique et Tectono-Sédimentaire. Thèse doctorat es Sciences. Univ. Tunis, 278 p. 1995.

[34] Bedir, M., Mécanisme géodynamique des basins associés aux couloirs de cisaillements de la marge atlasique de la Tunisie : sismostratigraphie, sismotectonique et implications pétrolières. Thése Doct.Univ. Tunis II, Fac. Des Sci. De Tunis, 416p. 1995.

[35] Hlaiem, A., Halokinesis and structural evolution of the major features in eastern and southern Tunisian Atlas. Tectonophysics 306, 79-95. 1999.

[36] Bedir, M., Boukadi, N., Tlig, S., Ben Timzal, F., Zitouni, L., Alouani, R., Slimane, F., Bobier, C., Zargouni, F., Subsurface Mesozoic Basins in the Central Atlas of Tunisia, tectonics, sequence deposit distribution and hydrocarbon potential. American Association of Petroleum Geologists Bulletin 85, 885-907. 2001.

[37] Riley, P., Gordon, C., Simo, J.A., Tikoff, B. and Soussi, M., Structure of the Alima and associated anticlines in the foreland basin of the southern Atlas Mountains, Tunisia. Lithosphere; v. 3; no. 1; p. 76-91, 2011.

[38] Rigane, A., Gourmelen, C., Inverted intracontinental basin and vertical tectonics: The Saharan Atlas in Tunisia. Journal of African Earth Sciences 61,.109-128, 2011. 


\section{INTERNATIONAL JOURNAL OF RESEARCH -GRANTHAALAYAH \\ A knowledge Repository}

Science

[39] Yaich, C., Etude géologique des chainons du Chérahil et du Khechem el Artsouma (Tunisie Centrale) ; Thèse Doct. 3éme cycle Géol. App., Univ. Franche-Comté, 119-123. 1984.

[40] Turki, M.M., Polycinématique et contrôle sédimentaire associé sur la cicatrice Zaghouan-Nebhana. Thèse Doctorat Es Sciences, Univ. Tunis, 262p, 1985.

[41] Ouali, J., Structure et évolution géodynamique du chaînon Nara-Sidi Khalif (Tunisie centrale). Bulletin des centres de recherches exploration-production Elf-Aquitaine 9,155-182. 1985.

[42] Ouali, J., Tricart P., Deltail J., Ampleurs et significations des recouvrements anormaux dans l'Axe Nord-Sud (Tunisie centrale), données nouvelles dans le chaînon Nara-Sidi Khalif. Eclogae Geologicae Helvetiae 80, 685-696. 1987.

[43] Abbès, C., Structurations et évolutions tectono-sédimentaires mésozoïques et cénozoïques associées aux accidents réghmatiques à la jonction des marges téthysienne et nord-africaine (chaîne Nord-Sud, Tunisie centrale). Doctorat d'Etat, Université Tunis El Manar (Tunisia), 440p. 2004.

[44] Ouali, J., Importance du réseau réghmatique dans la tectonogenèse de la Tunisie atlasique à travers l'étude de l'axe Nord-Sud. Thèse ès Sciences, Université Tunis El Manar, Tunisie, 399 p. 2007.

[45] Kamoun, Y., Etude néotectonique dans la région de Monastir-Mahdia (Tunisie orientale). Thèse de Doctorat de Spécialité (unpublished), Université d'Orsay, Paris XI, France, 175p. 1981.

[46] Haller, P., Structure profonde du Sahel tunisien. Interprétation géodynamique. Thèse de Doctorat de Spécialité (unpublished), Université de Besançon, France, 163p. 1983.

[47] Ellouz, N., Etude de la subsidence de la Tunisie Atlasique, Orientale et de la mer pélagienne. Thèse 3éme cycle, Univ. Pierre et Marie Curie, Paris. 126p. 1984.

[48] Khomsi, S., Géodynamique des bassins paléogènes et des réservoirs associés du Sahel de Kairouan (Tunisie orientale) : structuration, sismotectonique et organisation séquentielle, implications pétrolières. Thèse Doctorat (Ph.D), Université Tunis El Manar, Tunisie, 365 p. 2005.

[49] Busson, G., Mesozoic of Southern Tunisia. Guidebook to the Geology and History of Tunisia, P.E.S.L., 9th Annual Field Gonf., Tripoli, 131-152. 1967.

[50] Burollet, P.F., Desforges, G., Dynamique des bassins néo-crétacés en Tunisie. Livre Jubilaire Gabriel Lucas. Mémoire de Géologie, Université de Dijon (France) 7, 381- 389. 1982.

[51] Bouaziz, S., Turki, M.M., Zouari, H., Barrier, E., Tectonique en extension et failles de transfert jurassiques dans la région de Tébaga de Mednine (Tunisie méridionale). Ann. Soc.

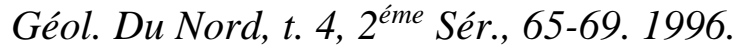

[52] Bouaziz, S., Barrier, E., Turki, M.M., Tricart, P., La tectonique permo-mésozö̈que (anté- 


\section{INTERNATIONAL JOURNAL OF RESEARCH -GRANTHAALAYAH \\ A knowledge Repository}

Science

Vraconien) dans la marge sud téthysienne en Tunisie méridionale. Bulletin de la Société Géologique de France 170 (1), 45-56. 1999.

[53] Alyahyaoui, S., Etude géophysique et cartographie de l'aquifère du Crétacé supérieur (Complexe Terminal) de la partie sud-est de la plaine de la Jeffara: implication hydrogeologiques. Mastère, Faculté de Sciences de Tunis, 142 p. 2009.

[54] Alyahyaoui, S., Gabtni, H., Jallouli, C., Gaubi, E., Hasn,i W., Jaffal, M., Kchikach, A., Apport de la géophysique à la cartographie de l'aquifère du Crétacé supérieur (Complexe Terminal) de la partie Sud-Est de la plaine de la Jeffara: Implication hydrogéologiques. Annales des Mines et de la Géologie $N^{\circ}$ 44. p.p 41- 55. 2011.

[55] Gabtni, H., Alyahyaoui, S., Jallouli, C., Hasni, W. and Mickus, K.L., Gravity and seismic reflection imaging of a deep aquifer in an arid region:Case history from the Jeffara basin, southeastern Tunisia. Journal Africain of Earth Sciences. 2012.

[56] Alyahyaoui, S., Gabtni, H., Jallouli, C., Contribution de la sismique réflexion pour la cartographie d'un aquifère profond: Exemple du l'aquifère du Crétacé supérieur (Complexe Terminal) au Sud-Est de la Tunisie. Journal of Advanced Research in Science and Technology ISSN: 2352-9989; 2(1): 153-172. 2015.

[57] Burrolet, P.F., Dumon, E., Carte géologique de la région de Porto Farina 1:50,000, 1952. Edit Serv Géol (ONM), 1949.

[58] Jauzein, A. Carte géologique de la région de Ariana 1:50,000, 1952.Edit Serv Géol (ONM), 1962.

[59] Pini, S., Kchouk, F., Carte géologique de la région de Porto Farina 1: 50,000, 1952. Edit Serv Géol (ONM), 1965.

[60] Rigo, L., Garde, S., El Euchi, H., Bandt, K., Tiffert, J., Mesozoic fractured reservoirs in a compressional structural model for the North-Eastern Tunisian atlasic. Proceedings of the 5th Tunisian Petroleum Exploration and Production Conferences, Tunis, 233-255. 1996. 


\section{INTERNATIONAL JOURNAL OF RESEARCH -GRANTHAALAYAH

\section{FIGURES CAPTIONS}

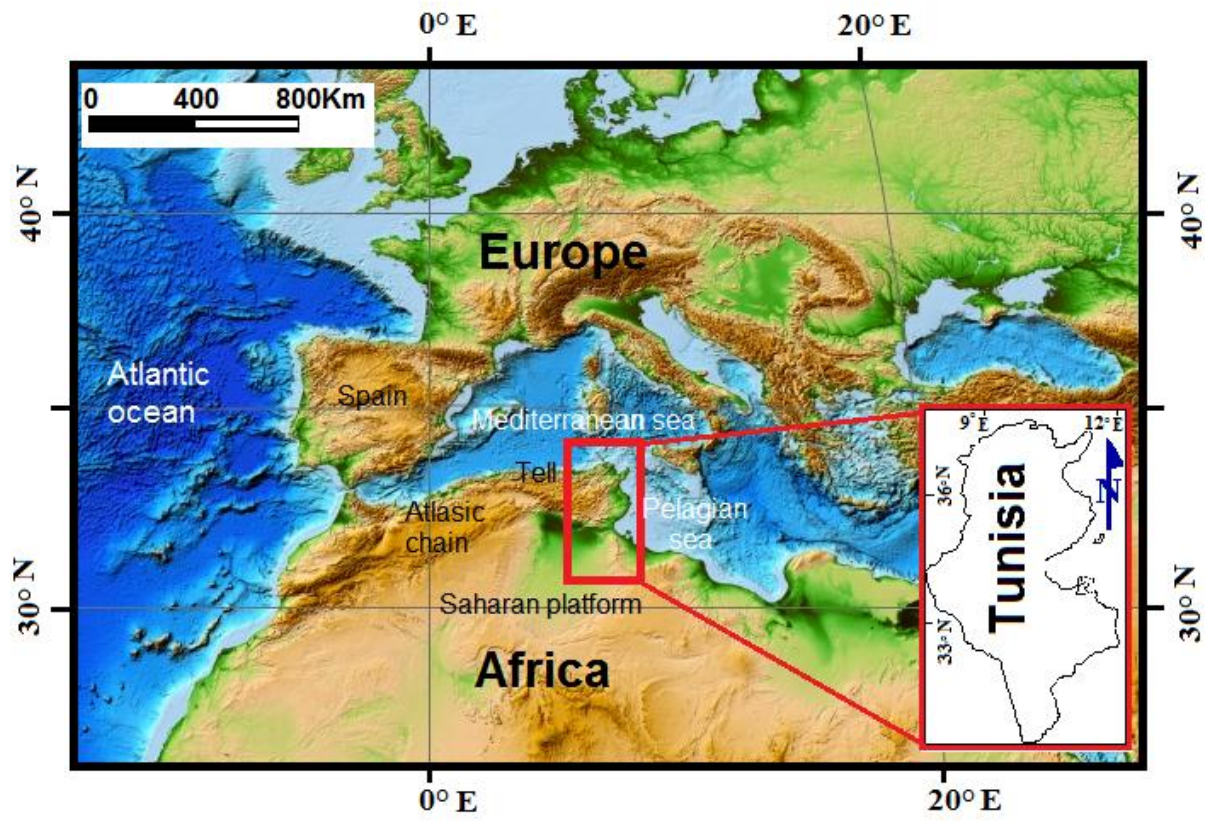

Figure 1: Digital Elevation Model (DEM) of Mediterranean Sea domain showing the generally decreasing altitude from north (Atlasic domain) to south (Saharan platform). Boxed area indicates location of the Tunisia region.

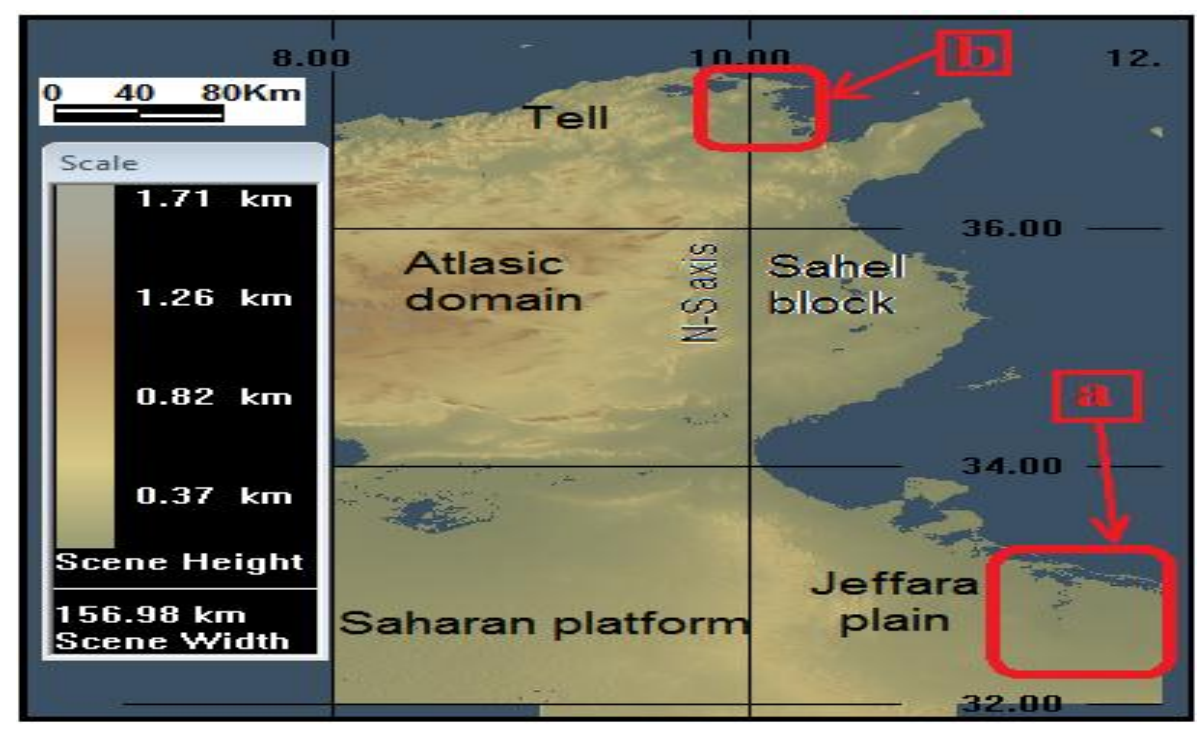

Figure 2: Digital Elevation Model of Tunisia. (a) Boxed area indicates location of the Southeastern of Tunisia. (b) Boxed area indicates location of the north-eastern of Tunisia. 


\section{INTERNATIONAL JOURNAL OF RESEARCH -GRANTHAALAYAH}

A knowledge Repository

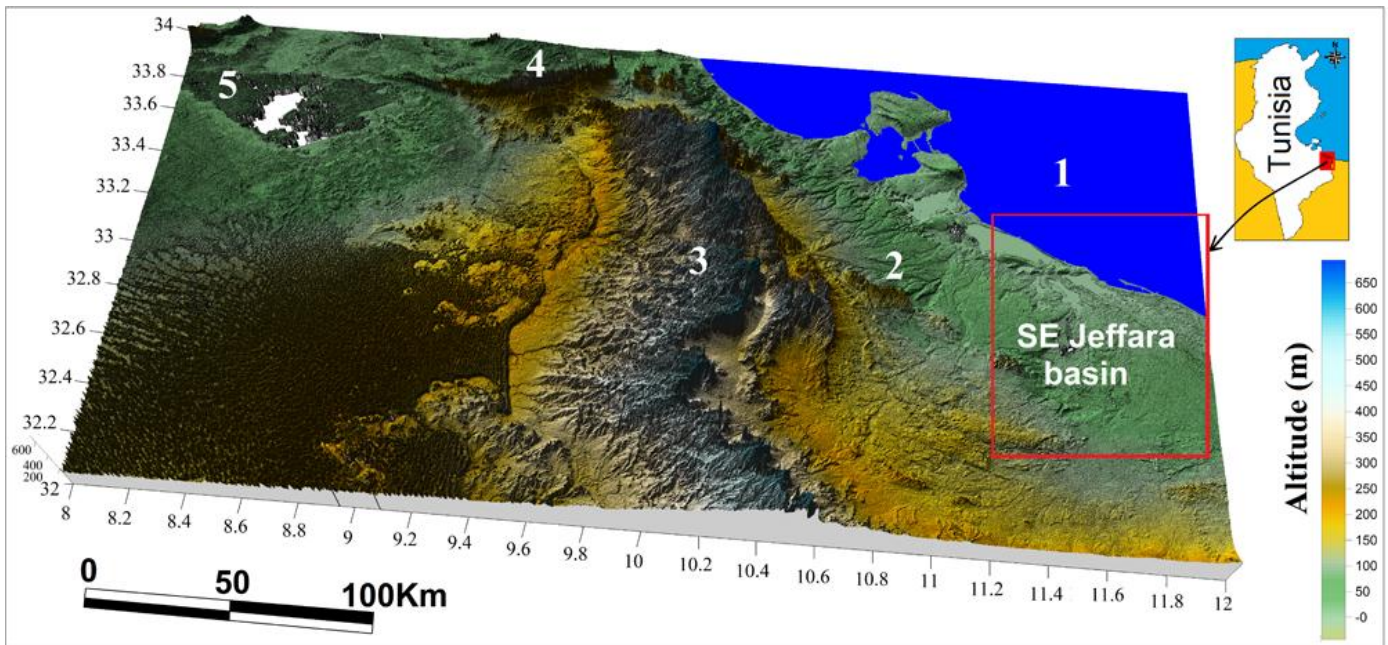

Figure 3: Digital Elevation Model of the South-eastern of Tunisia. 1: Mediterranean Sea, 2: SE Jeffara basin, 3: Dahar, 4: Jebel Tebaga, 5: North chain chotts

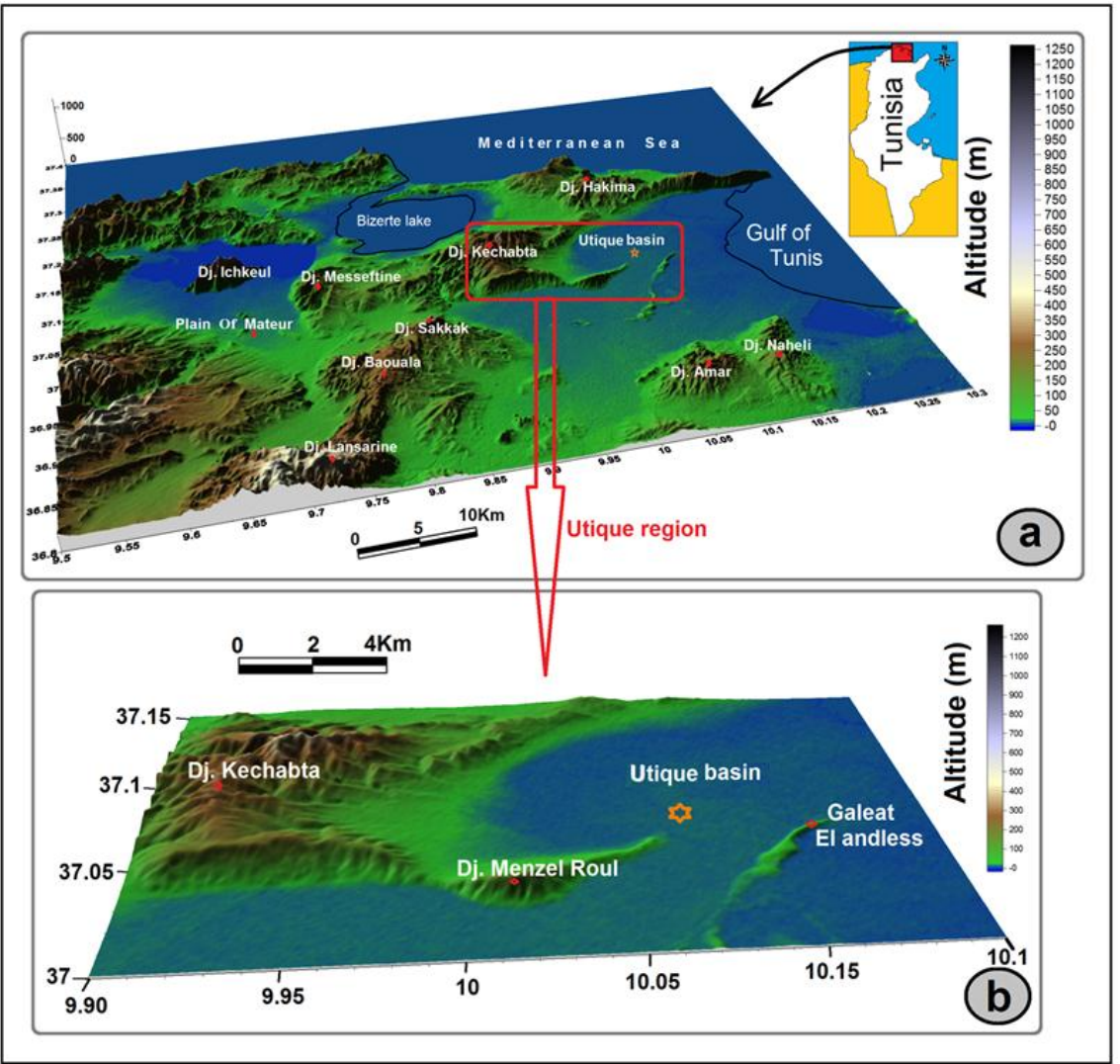

Figure 4: Digital Elevation Model of the north-eastern of Tunisia. 


\section{INTERNATIONAL JOURNAL OF RESEARCH -GRANTHAALAYAH

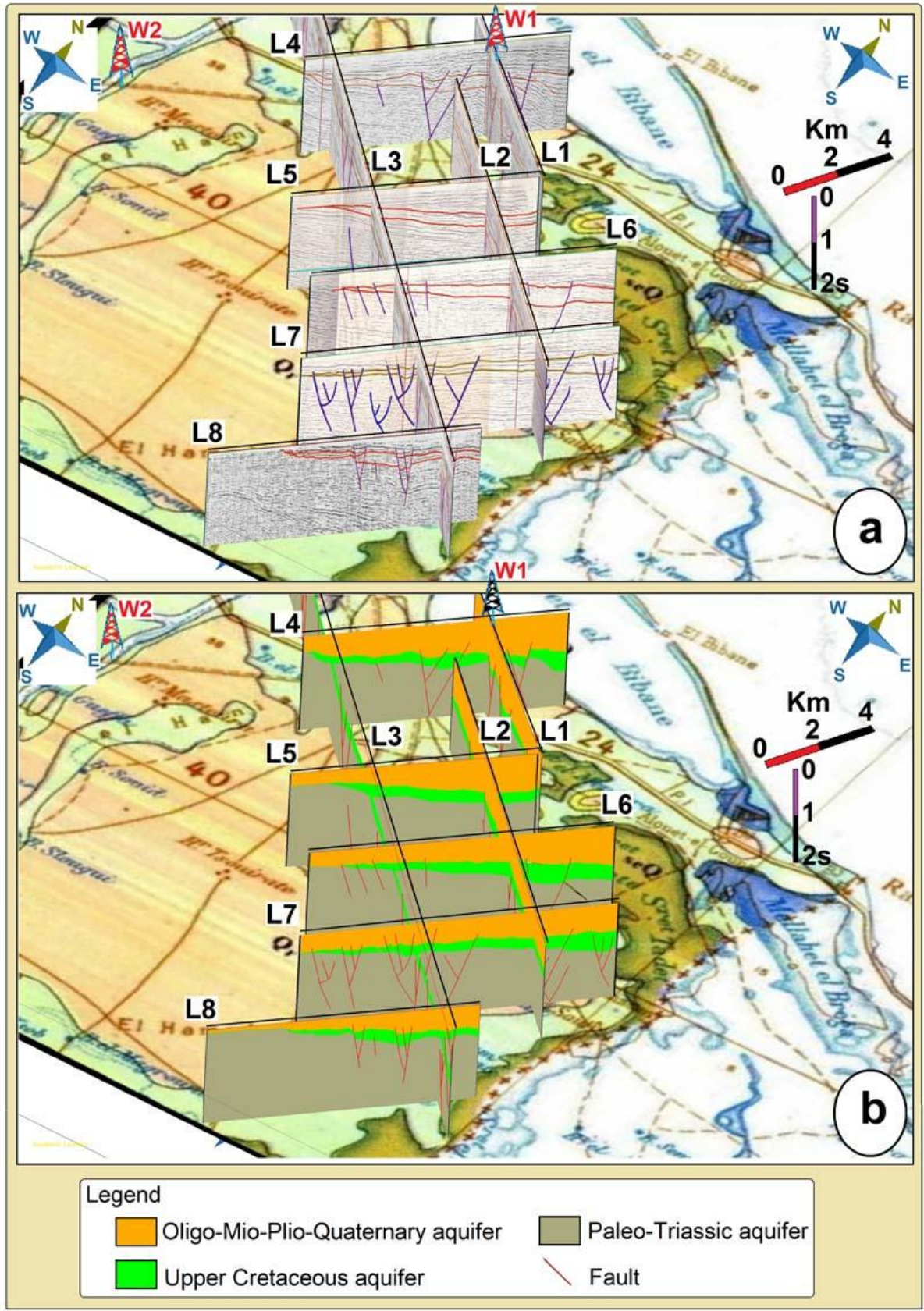

Figure 5: Determination of aquifers in Jeffara basin.(a) Interpolation of seismic profiles and maps at scale 1/500.000 of the south-eastern of Tunisia. (b) Interpretation of seismic profiles view 3D of interpretation of Complex Terminal aquifers. 


\section{INTERNATIONAL JOURNAL OF RESEARCH -GRANTHAALAYAH

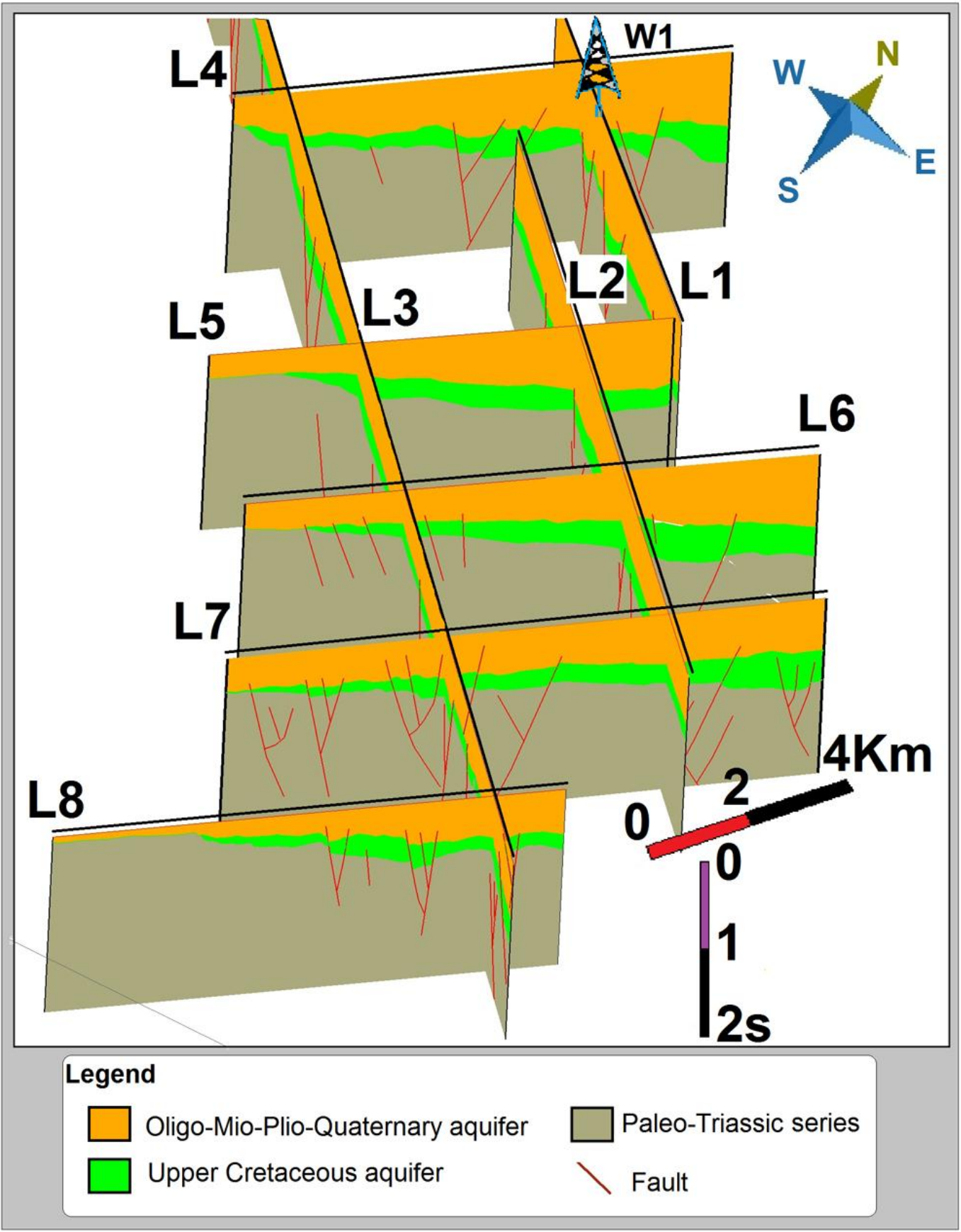

Figure 6: View 3D of geometry of aquifers of Jeffara basin. 


\section{INTERNATIONAL JOURNAL OF RESEARCH -GRANTHAALAYAH}

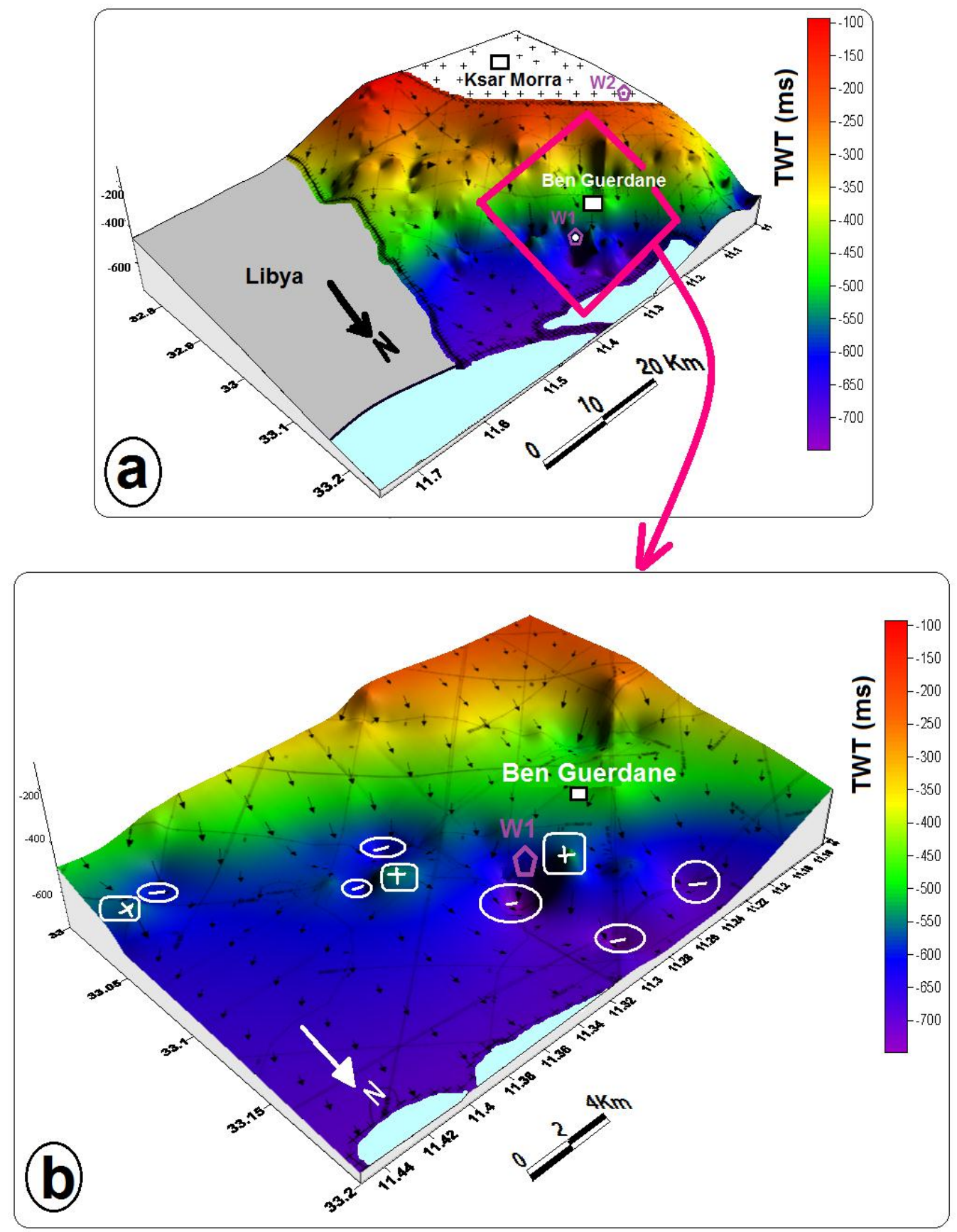

Figure 7: View 3D of geometry of top of Upper Cretaceous aquifer of Jeffara basin. (a) Top of Upper Cretaceous aquifer. (b) Detailed of 3D Top Upper Cretaceous aquifer in South-eastern of Jeffara basin. 


\section{INTERNATIONAL JOURNAL OF RESEARCH -GRANTHAALAYAH}

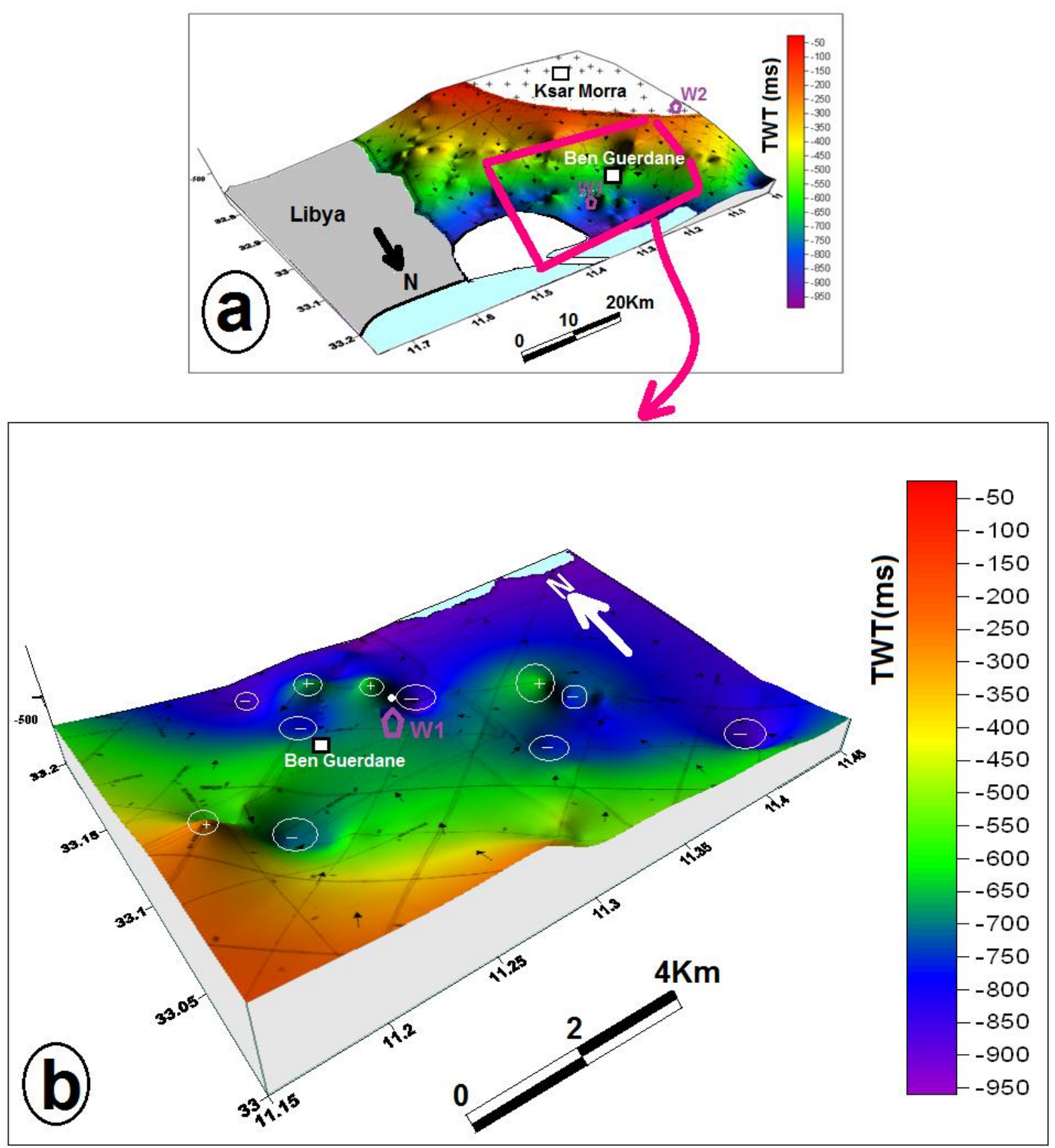

Figure 8: View 3D of geometry of Bottom of Upper Cretaceous aquifer of Jeffara basin. (a) Bottom of Upper Cretaceous aquifer. (b) Detailed of 3D Bottom Upper Cretaceous aquifer in South-eastern of Jeffara basin. 

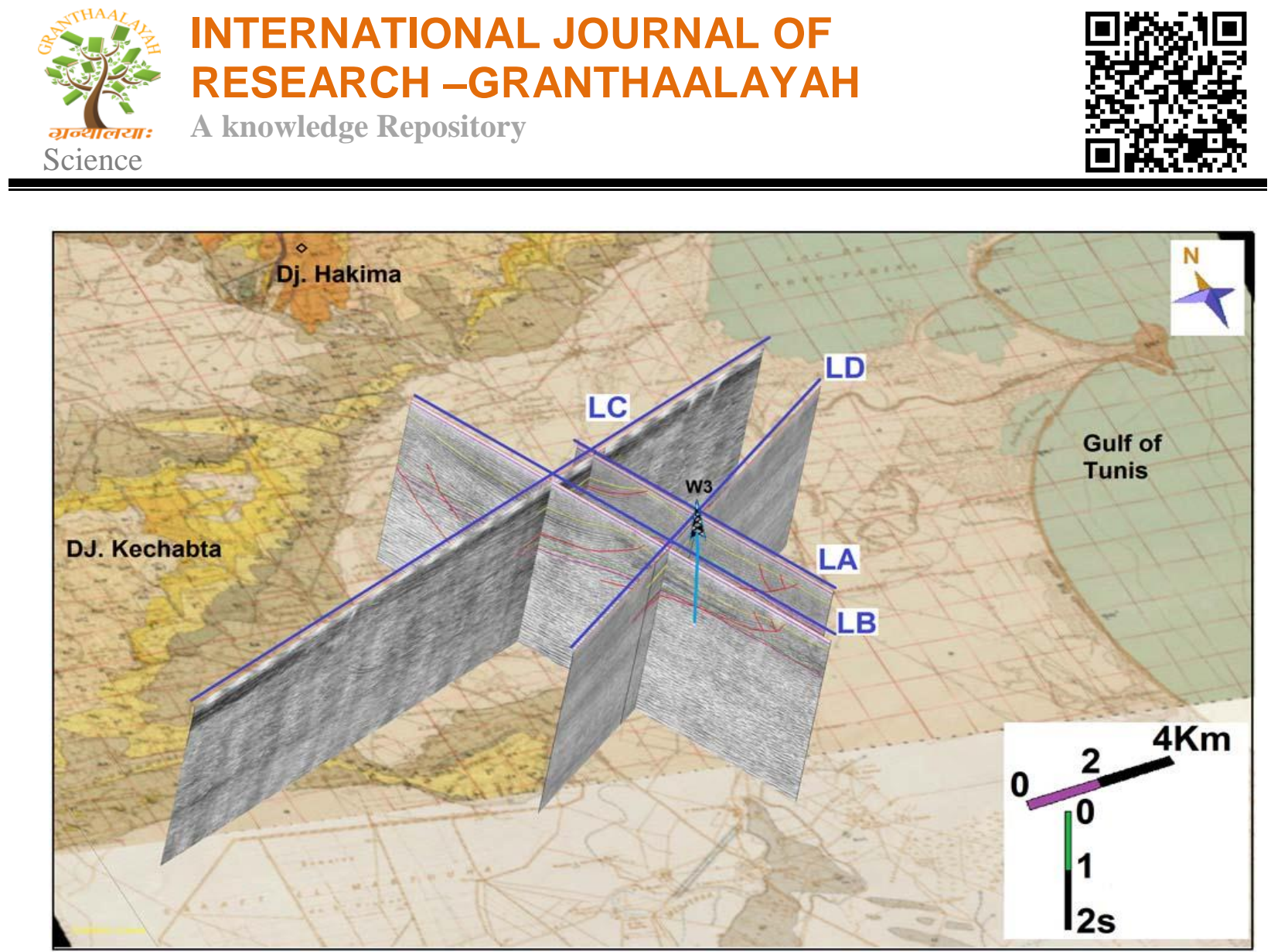

Legend

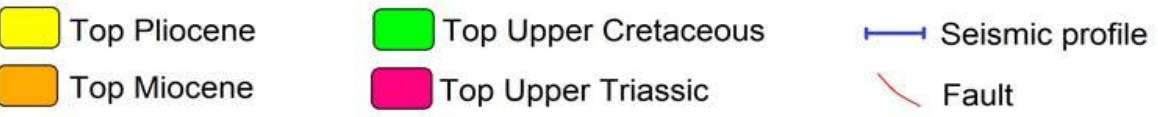

Figure 9: Interpolation of seismic profiles and maps of Porto-Farina and Ariana (1/50000) and determination of aquifers. 


\section{INTERNATIONAL JOURNAL OF RESEARCH -GRANTHAALAYAH}

A knowledge Repository
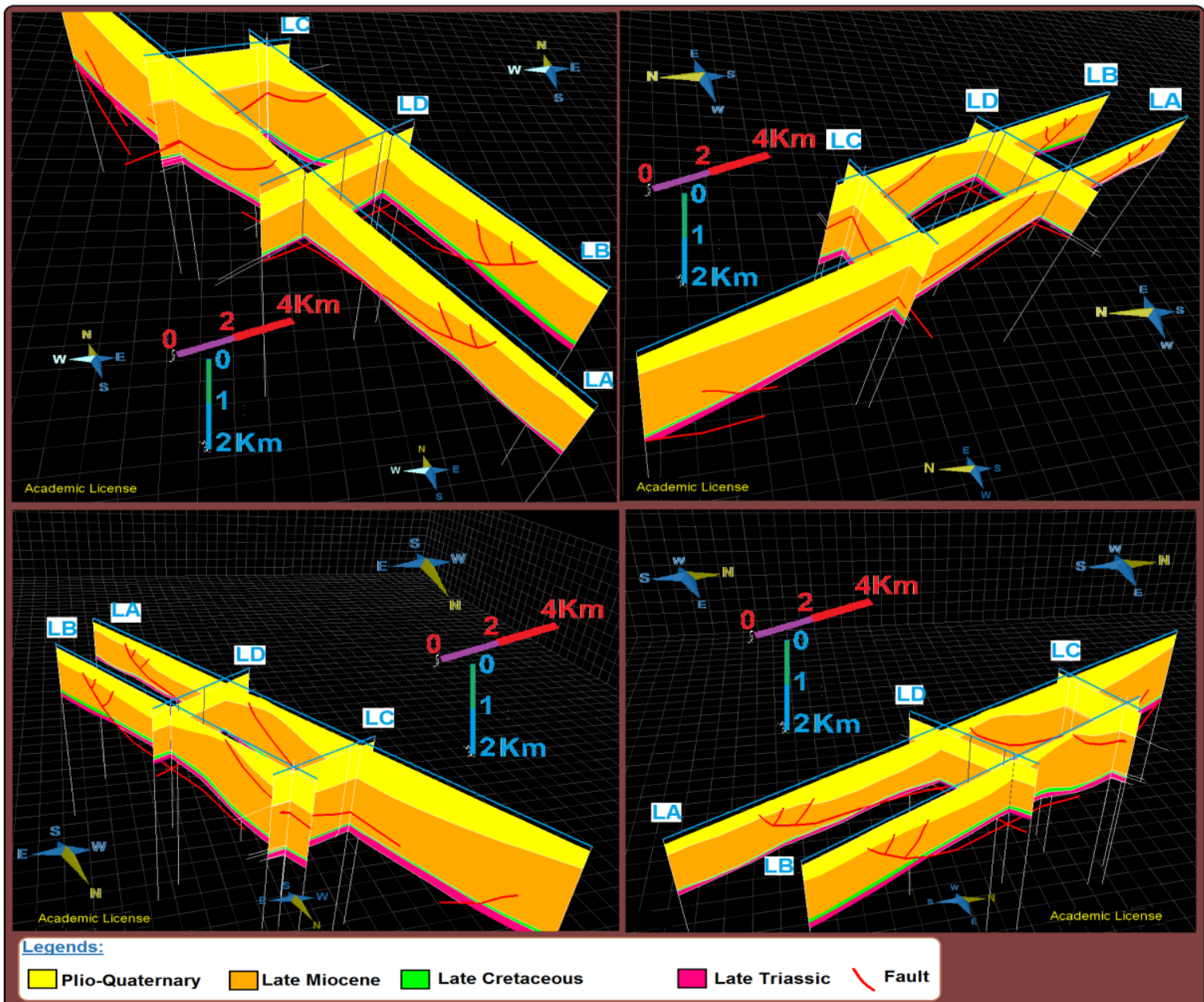

Figure 10: different view 3D of interpretation in polygone of seismic profiles of series. 


\section{INTERNATIONAL JOURNAL OF RESEARCH -GRANTHAALAYAH

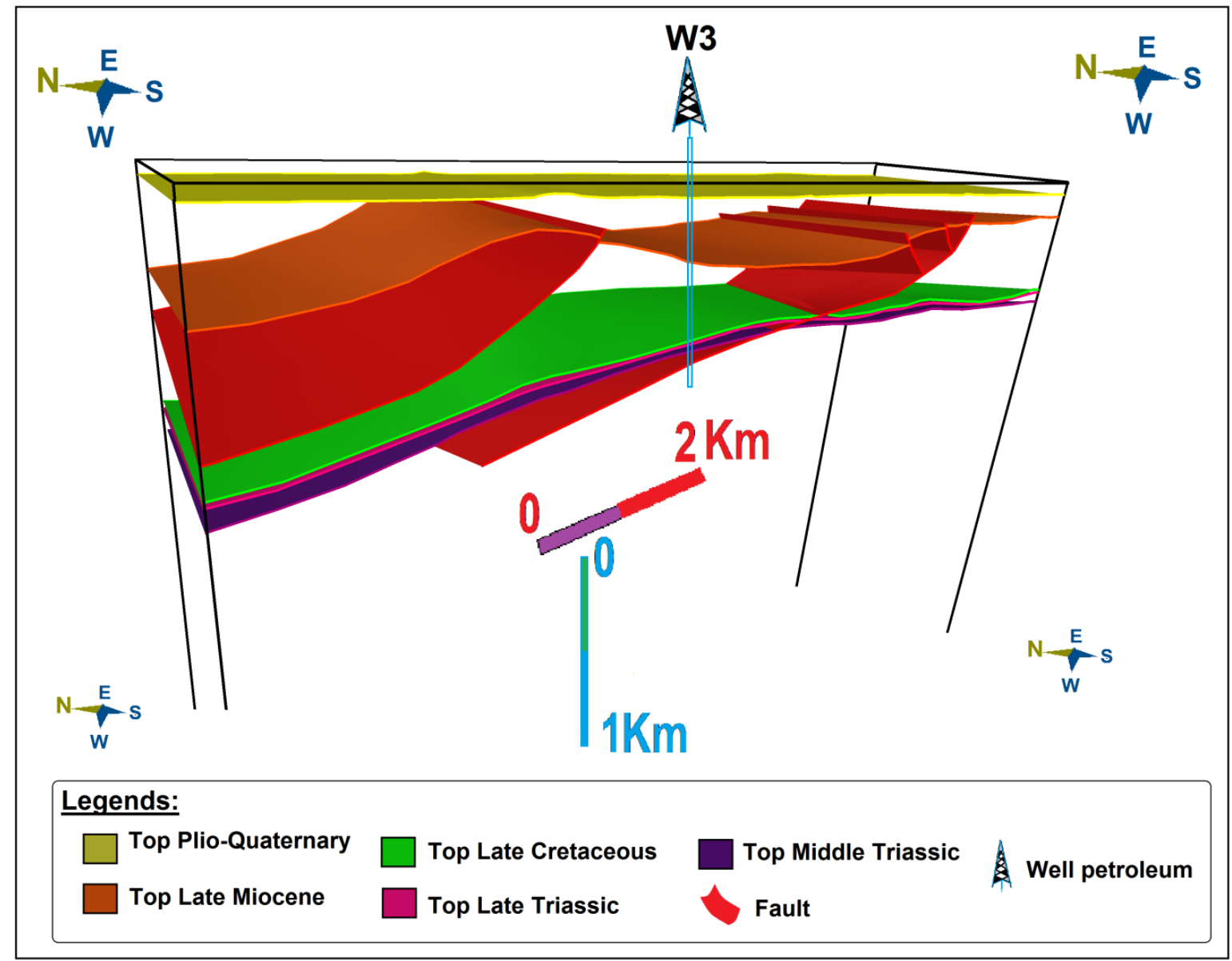

Figure 11: 3-D view of geometry in subsurface of aquifers. 


\section{INTERNATIONAL JOURNAL OF RESEARCH -GRANTHAALAYAH}

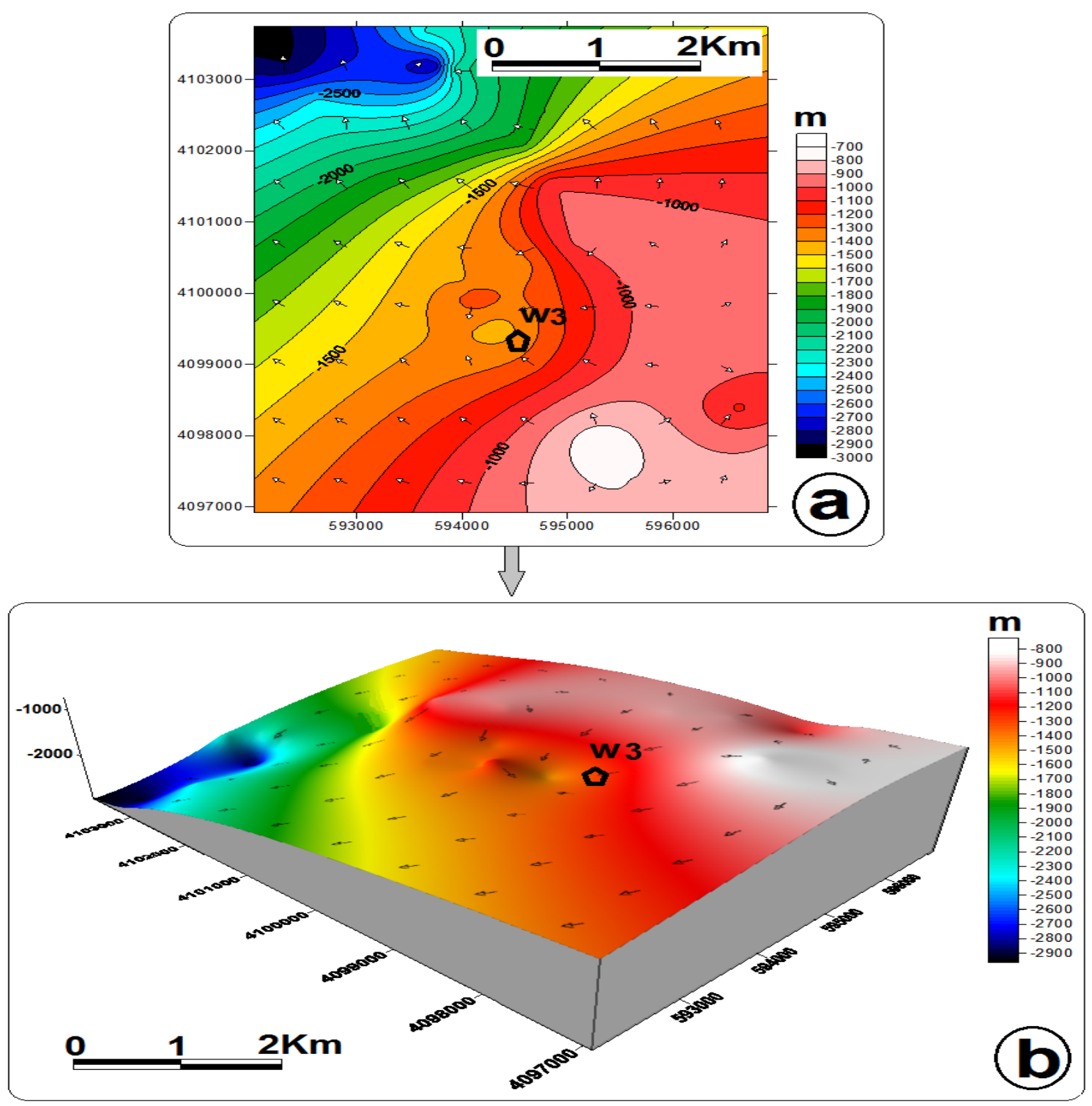

Figure 12: Top of the late Triassic aquifers (meters). (a) Contours maps of top of Triassic aquifer. (b) 3-D block diagram representation of the top depth distribution in the study area of late Triassic aquifer in meters. 